\title{
FOREGROUNDING OF POSTCOLONIAL ELEMENTS IN HANIF KUREISHI'S THE BLACK ALBUM
}

\author{
Muhammad Azeem $^{1 *}$, M. K. Sangi ${ }^{2}$, Komal Ansari ${ }^{3}$ \\ ${ }^{1 *}$ Ph.D., Scholar, University of Sindh, Jamshoro, Pakistan; ${ }^{2}$ Professor, Institute of English Language \& Literature, \\ University of Sindh, Jamshoro, Pakistan; ${ }^{3}$ Associate Professor, Institute of English Language and Literature, University \\ of Sindh, Jamshoro, Pakistan. \\ Email: ${ }^{1 *}$ cdglmuhammadazeem@gmail.com, ${ }^{2}$ sangi_mk@yahoo.com, ${ }^{3}$ komal.ansari@gmail.com \\ Article History: Received on $3^{\text {rd }}$ June 2021, Revised on $16^{\text {th }}$ June 2021, Published on $19^{\text {th }}$ June 2021
}

\begin{abstract}
Purpose of the study: This study aims to examine the postcolonial elements i.e, hybridity, mimicry, and ambivalence concerning Hanif Kureishi's novel The Black Album (1995). The protagonist of the novel faces religious, economic, social, racial, and ethnic identities in a tormenting and perturbing social order of England.

Methodology: This article is based on inductive reasoning and thus exploratory due to its qualitative nature. A close reading method is applied to the text of this paper. For this purpose, the researcher has read carefully the book Close Reading (The Basics 2018) by David Greenham. The method consists of five stages through which the paper scrutinized.

Main Findings: The researcher endeavors to find out religious, economic, ethnic, cultural, and social factors behind the identity crisis faced by the protagonist. Hybridity, mimicry, assimilation, and ambivalence play a very vital role in the social life of the protagonist. The researcher found that Shahid Hassan is caught between two identities i.e, Islamic fundamentalism and liberalism. Islamic fundamentalism offered him much peace and satisfaction with the Islamic religion whose leader is Riaz Al Husain but the liberalism attracts his attention with drugs, sex, music, freedom, rock n` rolls, and carefree life in form of Deedee Osgood who is his mentor and is a college lecturer too. He becomes the victim of hybrid identity and remains in an ambivalent state of mind. Being a British immigrant, he always remains in search of his true identity. Being a postcolonial novel, it helps the students, teachers, and literature lovers to know about the biased and rude behaviour of the whites towards non-whites.
\end{abstract}

Application of the study: Foregrounding of postcolonial elements is very significant only in the field of postcolonial study because it highlights economic, religious, political, social, cultural, and ethnic factors of identity crisis.

Novelty/Originality of this study: This study is an original contribution as it examines the economic, political, racial, social, and ethnic issues faced by the protagonist. The researcher employed Homi Bhabha's postcolonial elements to examine the identity crisis faced by the protagonist. Moreover, the close reading method for data analysis is based on originality as well as novelty.

Keywords: Islamic Fundamentalism, Liberalism, Immigrants, Diaspora, Tormenting, Hybridity, Ambivalence.

\section{INTRODUCTION}

A novel by a British Muslim of Pakistani descent, Hanif Kureishi's The Black Album intertwines a bildungsroman narrative of a young British Pakistani with a commentary of the contrasting cultures faced by the protagonist. Set in 1989, the setting of an ever-urbanizing London amidst its swing back from 1960's counterculture, in what could be termed as a Freudian return of the repressed, provides Kureishi with a vibrant landscape to investigate the postcolonial theory of hybrid identity, mimicry, and ambivalence as a new way of life. Published in 1995, the novel shares its title with musical artist Prince's 1994 album. It is being "half black and half white, half-man, half-woman, half size, feminine but macho, too", underlines Kureishi's main argument of deconstructing fixed identity in favor of a fluid system, to prevent individuals from being oppressed by their own identity. The novel's protagonist, Shahid Hassan, idolizes Prince as a "river of talent". The reader can determine the pop star as a signifier of change, at a time when Ayatollah Khomeini's fatwa against Salman Rushdie had fuelled the inception of neo-fascistic Islamic religious structures.

The novel discusses the different ideologies of Islamic fundamentalism and modernism, as the protagonist faces a confusion of wanting "to belong to his people", but also want to experience unlimited pleasure. Kureishi allegorically represents the two opposing ideas in the mentors which Shahid serves simultaneously whilst he is undecided which to pledge allegiance to. Firstly, he is drawn in by Riaz Al-Hussain, his neighbor and the leader of a group of Muslim students at his college. Riaz's version of Islamic fundamentalism, although attractive in terms of brotherhood and having strong cultural values, is an extremely virulent form of authority and becomes tainted by its attitudes towards women, morality, and literature. Shahid's other mentor is Deedee Osgood, his tutor at the college with whom he engages in an extremely physical affair, and the values she espouses resemble the anarchy of consumerism, but in facilitating Shahid's experimentation with sex and drugs, she stimulates his imagination. While Shahid Hassan always tries to take interest in liberalism and attended the lectures of his mentor regularly. The thematic uses of characters, along with the indecisive and "tepid" Shahid, alienate the characters from the reader, instead of reading as plot tools. They make the novel seem more like an argument at times and there is an obvious bias toward the imagination and literature by Hanif Kureishi, a lifelong writer. Although the characters are flawed, Kureishi's use of narrative structure in The Black Album is a strength 
of this novel. The oscillating nature of his protagonist's ideas are mirrored in the novel's loose construction, and even when the arresting sequence does finally arrive, as Riaz and friends burn The Satanic Verses in a show of aggression against the freedom of speech, Shahid as the young hero still wants to "appear neutral". In the end, however, for the sake of love and pleasure, he sacrifices his culture and religion. He is always in quest of his cultural and religious identity.

He is entangled between two cultures because he is concerned with the plight of the immigrant's identity and he introduces a variety of different subjects related to identity crisis. Such kind of issue is tragic as well as painful but Kureishi calls them as growth and creativity. The Black Album reveals the same theme as what Rushdie has said of The Satanic Verses before. It also highlights fraternizing, transformation, and the protagonist's struggle to face the different cultures that play upon his mind and feelings. That is why, Shahid remains in an ambivalent state of mind throughout the story of the novel.

Moreover, the 1970s England period was full of severe political and social discontent. With the 1979 election, the liberalism characterized the 1960s experienced a sharp spring towards conservatism. At this time, the British government failed to serve their immigrants totally, thus a political Liberal party emerged in England as a result of this failure. At that time, the unemployment rate, downfall of the economy, the lack of educational and health facilities were very common and the British government could not solve the problems of its citizens. From 1978 to 1979, the difficulties reached at a peak when a large number of union workers went on strike and protested on their pay against the so-called Winter of Discontent. Gilbert (2001, p. 127-128) indicates that by the passage of time, the middle-class immigrants tried to maintain their lives with difficulties. This social and political discontent also affected the social and religious life of Shahid Hassan. He took a great involvement and interest in this political movement. The alarming racist attitudes are also observed by him. He felt the atmosphere of Great Britain is based on conservatism which results later in racism. He thinks of racism as a result of Great Britain's division of its colonies along with the division of the subcontinent into two independent states i.e., Pakistan and India approximately 25 years ago.

\section{Research Questions}

The current research paper seeks to search for the answers to the following research questions.

1. What are the factors behind Shahid's identity crisis?

2. How does the British culture play a significant role in the social, religious, economic, and political life of the protagonist?

3. How does Shahid's hybrid identity create a sense of ambivalence in his state of mind?

\section{Research Objectives}

The objectives of this research paper are

1. To explore the factors behind Shahid's identity crisis.

2. To highlight the effectiveness of British culture in terms of the social, religious, economic, and political life of the protagonist.

3. To elaborate on the protagonist's hybrid identity and his sense of ambivalence.

\section{LITERATURE REVIEW}

The postcolonial criticism viewed the work of Hanif Kureishi as full of racial tension, color binary, hybrid culture, identity crisis, class distinction, and gender role. He introduces in his fiction the world of discrimination and differences, color binary, and religious issue. So a lot of critics put their valuable comments on the dilemma of hybrid identity regarding the protagonist of the novel The Black Album. A famous critic Walsh (2008) in his book In Betweeners, discusses Kurieshi's art of attracting his readers and keep them busy to know about the British culture, its history, and traditions. He also introduces in his fiction the Asian culture and its traditions about first-generation immigrants. Walsh (2008) questions the past historical life of a particular protagonist and concludes it as full of cultural complexities and racial tension. Another critic Schoene (2009) in his Cosmo-political novel observes a change in the present British culture and its impacts on the protagonist's life. He links this change in British culture to the result of multiculturalism which is hard to pacify. Thomson (2005) in her Monograph on Hanif Kureishi feels the anxiety in the protagonist of the novel when he is undecided to join whether of Islamic fundamentalist group or a liberal group. While choosing any one of them, Shahid acts mimicry, feels ambiguity dislocation, alienation and uncertainty. According to Susie Shahid's growing uneasiness with the British culture and traditions is the indication of Britisher's biased attitudes towards him. Louis (2013) in his book Irrepressible adventures with Britannia: Personality, politics, and culture in Britain comments on The Black Album (1995) and finds the uncertainty, uneasiness, and inconsistency in Shahid's's life as a result of a change in British culture and its 1970s racist policy.

According to Sara Upstone (2008), Hanif Kureishi's novels depict racial discrimination, clashes with religions, differences between hybrid cultures and traditions. She perceives such racial discrimination and differences of cultures as the remembrance of British chequered history and its consequences on immigrants' life (Upstone 2008 p. 21). Hanif 
Kureishi depicts in his fiction the Westerner's biased attitude towards Muslim immigrants. Throughout his writing, he always seems to fights against the evils of racism while not feeling shame concerning friendship with black-skinned and go out Paki-bashing because he was himself a Pakistani by origin. Moreover, he has to express himself in his fiction too (Kaleta, 1998). Through their writings, sensitive people express their feelings like Hanif Kureishi. From a very early age, Hanif Kureishi saw western hatred for Muslims. The bitterness of racial attacks discloses his childhood experiences. Hanif Kureishi never wanted himself to be recognized as a Pakistani because according to him, the word Pakistani is an insult. The whites hated the word Pakistani (Kureishi as cited in Kaleta, 1998). Kaleta (1998) observes that Hanif Kureishi gives vent to his feelings through the character of Shahid Hassan.

The immigrants in Hanif Kureishi's novels always struggle to find their identity in a tormenting and perturbing social order of English society. According to Kaleta (1998, p. 14), White Johnny in My Beautiful Laundrette, Karim of The Buddha of Suburbia, Clint of London kills me and Shahid in The Black Album, all dreams of escaping the streets to find a land of opportunity, where they would spend their carefree life and where they can achieve progress easily in their future. But all these characters go through the process of racial otherings. The British immigrants' policies become the hurdle in their ways resultantly restlessness and dislocation and uncertainty in their life. Therefore, Hanif Kureishi very well discussed in The Black Album the Muslim frustrations and ambivalence through the character of Shahid. Gilbert (2002, p. 4) observes the formal decolonization in psychological, political, cultural, and material terms through Hanif Kureishi's thinking approach. According to Upstone (2008), Hanif Kureishi's The Black Album is a metaphorical and literal representation of cultural differences and world tension. She observes that the racial intolerance and British racism in the story still remind us of the reign of Margaret Thatcher's so-called migrant policies (Upstone, 2008, p. 210). Ossowska in his research article entitles "The Rushdie Affair - Politics, Culture and Ethnicity in Hanif Kureishi's The Black Album" In this paper, he examines the implications of the Rushdie Affair, and the identity crisis faced by the protagonist in British society.

Two opposing identity options taken by the protagonist are analyzed by the author. Grin (2000) describes the role of food in his term paper entitles, "The role of food and consumption in Kureishi's The Black Album" In this paper, the author explores three kinds of food i.e, Chilli, holy aubergine, and consumption of the drug. The novel depicts Shahid's quest for identity while his living between two opposite groups. The word Chilli is the symbol of hot and spicy here. It is also the name of Shahid's elder brother. Chili like his name meaning wants to help Shahid hotly and speedily. The holy aubergine (fruit tree) acts as a symbol, the symbol of liberty for the Muslims and safeguard of their religion. The consumption of the drug is the symbol of sex through which Deedee invites Shahid to different pubs and parties where people abuse drugs. So the role of food and consumption highlights clashes of religion between liberal and Muslim fundamentalist groups.

\section{APPLICATION OF THEORY}

For the analysis of Shahid's quest for identity, the researcher employs Homi Bhabha's postcolonial/postmodern elements, hybridity, mimicry, ambivalence, and the third world into the text of the present paper. He defines hybridity as the emergence of one or more than one culture and in consequence, a new form of culture exists which is called hybridity or third space, (Bhabha, 1994, p.122). Through the repetitive effects of the discriminatory identity, it is the revaluation of the colonial identity. The displacement and deformation of all the discrimination and domination can be viewed by hybridity, (Bhabha, 1994, p. 112). According to Bhabha, hybridity is the result of mimicry which exists due to immigrants' imitation of the cultural values of the host country. But this mimicry never fetched the desired effects and the result is simply ambivalent for them, (Bhabha, 1994, p.124). The protagonist, Shahid Hassan tries to imitate the cultural values of his mentor Deedee Osgood to assimilate himself with the British culture and traditions but in consequence of this, he remains in an ambivalent state of mind. Ranasinha, 2002, p. 25) argues such ambivalence provides the epistemological warrant for a comprehensive understanding of The Black Album as it creates uncertainties in him. He is a hybrid character genetically too because, from his father's side, he belongs to Indian heritage, while from his mother's side, he belongs to English heritage. Such a sense of belongingness creates ambiguity, uncertainty, and absurdity in his mind as Ranasinha (2002) observes. Furthermore, the present research paper fills up the gap for further research on political, religious, and economic factors rather than ethnic, social, racial, and gender issues of an identity crisis as well.

\section{RESEARCH METHODOLOGY}

This article is based on inductive reasoning and thus exploratory due to its qualitative nature. A close reading method is applied to the text of the present article. For this purpose, the researcher read carefully the book Close Reading (The Basics 2018) by David Greenham. This method highlights the detailed scrutiny of the textual data available for the study. I employed the close reading method for the analysis of textual data which usually consists of five stages i.e, first the interpretation stage, second critical analysis stage, third evaluation, fourth verifying stage, and the last called the writing stage in which the researcher writes his useful comments in form of a manuscript. The researcher followed all these stages one by one and thus gives the conclusion.

\section{FOREGROUNDING OF POSTCOLONIAL ELEMENTS}

In this paper, I propose to deal with the problem of identity crisis faced by the protagonist in Hanif Kureishi's The Black 
Album by employing Bhabha's postcolonial/postmodern elements. Hybridity, mimicry, assimilation, and ambivalence are the main elements that have been taken from Homi Bhabha's book The Location of Culture 1994. Initially, in this article, I will make a general framework on the identity crisis faced by the protagonist in the context of the novel and on the postcolonial works of literature that manifest the process by which the protagonist faced identity crisis in a tormenting and perturbing social order of England.

\section{THE ELEMENT OF HYBRIDITY IN THE BLACK ALBUM}

The present paper reveals Shahid's hybrid identity who abides by the Islamic rules and follows the Muslim fundamentalist group of Riaz Al Hussain but he joins the liberal group in form of Deedee Osgood too.

"I swallowed half and the person who gave it to me said I should come and see you.

That's the effect it had" (Kureishi, 1995, p. 56).

Why does Shahid represent his hybrid character?

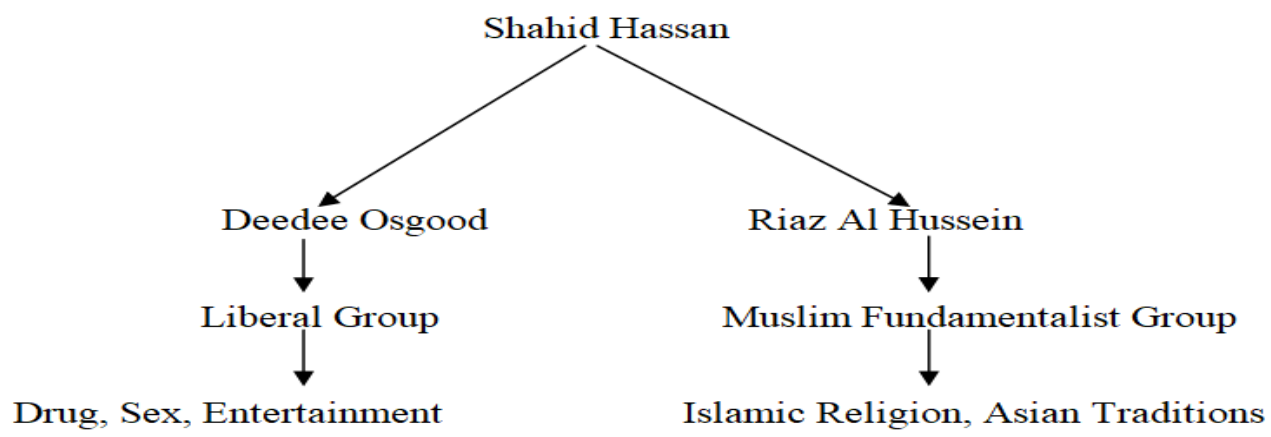

Figure 1: The above-mentioned flow chart shows Shahid's hybrid character and his engagement with different groups.

He is living in between two groups; one is the Muslim fundamentalist group of Riaz Al Hussain and other is the liberal group in form of Deedee who is a college lecturer but he prefers to join the liberal group. The liberal group in London attracts him with sex, drug, and entertainment. He has a keen interest in getting his education in London which shows not only the wealthy metropolis but also influences his mind and attitude that he is getting his education far from his homeland (Ranasinha, 2002 p. 73). His attachment with the western culture or powerful culture is the indication of his intense dislike for his culture and loss of his identification. He considers English culture as much better than that of weak Indian culture. Although Shahid's father is dead, he belongs to a rich family in Pakistan. He is the owner of two shops in the Kent area. That is why, he has a lot of money and could afford to develop his quest for self-identity. After meeting with Riaz Al Hussain, he was greatly influenced by him and his value system for his consistent creed. Riaz Al Hussain is a religious character and a leader of the Muslim fundamentalist group. He was born in Pakistan and later he migrated to London and became the leader of the group of Muslim fundamentalists in his college when for further education, he moved to London. Although he accepts his education in London, he hates to admit himself as an Englishman. He believes only in Islam. When they meet for the first time, Riaz talks with Shahid about the issue of identity. He says the Pakistani immigrants have their purpose and security to live in England. While pursuing security and purpose, they lost something like art and aesthetics and they are being laughed at by the white customers in their karaoke bars. Shahid Hassan shows his partial indignation towards Pakistanis by noticing them as lazy as possible which is not a loss of identity but a sense of shyness to his national culture. Being educated at Western Institute, Shahid does not know about his national culture and traditions. Edward Said observes Muslims are lazy and their politics as futureless and fickle. They are mystical having neither conception of history nor any nation unless they learn to be rational. However, Riaz Al Hussain in the novel asks the questions such as: What are his Pakistani companions looking for? What is their meaning of life? Through being there in western countries, it is difficult for them to maintain their national identities. According to other people's opinions, they are living as what Shahid Hassan is disputed more of uncommon than I did normally in that part of the country. You know they, I have been kicked around and chased a lot. This act made me full of fear. (Kureishi, 2009, p.6). "They gave us the language but it is only we who know how to use it".

Shahid is a hybrid character genetically too which interprets Bhabha's idea of hybridity.

"And where are you from?

'Lahore. Originally.'

'That "Originally" is quite a big thing' Shahid said.

The biggest thing of all. You recognize that eh?

I was brought away to this country at fourteen.” (Kureishi, 1995, p. 06) 
Why does Shahid represent himself as a hybrid character genetically?

He belongs to India and his mother belongs to England. That is why he is the breed of hybrid inheritance. Owing to his hybrid character, he seems always busy in quest of his original identity throughout the story of the novel. The whites make fun of his black skin as well as his hybridity. Shahid continuously observes the migration of human beings and their absorption of the culture of the host country. Even in Pakistan, some people disliked him and the condition is the same at present. He criticized Margaret Thatchers' reign as full of racial and anti-Muslim agendas. Even more, his school fellows chanted at him "Paki, Paki, Paki, Out, Out, Out!" (Kureishi, 1995, p. 15). Sometimes, a Bengali family put a hostile discrimination on Shahid and his friends. The family stared at and called Paki scum and finally attacked them. Shahid described Zulma that the racists would think them of Pakis and being frequented because we were intellectuals and had the status of being rich (Kureishi, 1995, p. 52). His psychological anxiety makes him paranoid when he thinks about these discriminatory things. He feels extremely uncertain conditions and in a serious mental illness. He calls about the whites that there is a bit of Hitler in all white people and believes racism being existed for a century and absorbs social bias in a colonial country already. His relatives admire English culture while being lived in Karachi. They enjoyed seeing movies from England and they like to drink bootleg alcohol. In Shahid Hassan's family, young people are fond of religion concerning a strong political feeling (Kureishi, 1995, p. 54).

Therefore, it can be said that the colonized lost their self-esteem and the collapse of their ego when they face a frustrated and awkward situation in England (Fanon, 1967, p.264). In The Black Album Shahid Hassan and Deedee Osgood become friends for good and they become the victim of hybridity or polyphyletic when Deedee Osgood divorced her husband and Shahid Hassan leaves his friends' union. According to Homi K. Bhabha, the colonized have a different vision of observing the world while on the other hand, the colonizer perceives a different vision of the world. However, according to Homi Bhabha, the colonized feel unholiness when they are hanging in two different cultures. The identity of the colonized perceives a double consciousness by two cultures. Such a double consciousness, double thought, and double social classes create double ideals and double words and inspire the colonized to revolt against the hypocrisy of the Londoners. According to Du Bois, the immigrant remains in this double consciousness and performs a disguised or fragmented life. In colonization, a paradoxical mental state exists as observed by Bhabha. According to him, when two cultures mixed and a new form of culture emerges and features of the previous culture transform into the new one. Bhabha calls this changing method as hybridity (Bhabha, 1994, p. 25). Bhabha states that identity is base on problems which is an image of the totality rather than a priori or a finished product (Bhabha, p. 51). He claims it as the black people's feeling of sense of superiority and white people's lack of self disdained. No doubt changes would happen through this dynamic progress regardless of what kind of identity they held in the past and what kind of identity they held in the present. Because of their different identities, Shahid Hassan and Deedee Osgood experience the adopting and repelling process actively but Shahid Hassan and Deedee Osgood are tangled with their inter-appealing personalities and their love relationship. Both of them have different believes about religion and they quarrel with each other because of this belief and Shahid's involvement in Islamic fundamentalism but this disagreement of religion between them mitigated when they actively come to sex. However, Shahid Hassan is in an uncertain condition to choose between liberal life with Deedee and Riaz's fundamental group. He is in a psychological conflict in a manner whether to adopt the Muslim fundamentalist group of Riaz Al Hussain or to follow the liberal group of Deedee Osgood. According to Shahid Hassan, the matter is about brotherhood and about joining one of the groups rather than a question about believing its truth or falsity. Indeed Shahid Hassan is worried about his personal and cultural identity and always remains in a state of an ambivalent condition. He feels ambiguity in every aspect of identity such as "man, woman, gay, black, Jew" (Kureish The Black Album). So Shahid Hassan is disappointed with the British weak culture.

\section{THE ELEMENT OF MIMICRY IN THE BLACK ALBUM}

Shahid Hassan urges to imitate the cultural values of England and joins the National political party when he says,

"I am a racist, Chad smacked the table. I already said you only a vessel,

I have wanted to join the British National Party" (Kureishi, 1995, p. 11).

Why does he want to join the British National party? Because of joining and imitating the cultural values of the whites, he may be assimilated himself with the British culture. For adjusting himself with the British culture, he tries to imitate the cultural values of the Whites but this mimicry never fetched the desired effects and the result is simply uncertainty for him. The Whites consider themselves as superior and supreme race as compare to immigrants especially the Asians, even though they do not take interest in them. That is why, Shahid's religious, personal, cultural, social, and political identities are the victim of disintegration. However, this idea is based on illusion because it indicates the false metaphysics of philosophical traditions of Western societies which have described discriminations as the refusal of hybrid and cultural identity and affixed this refusal to the minor group which is called Asian peoples. The novel shows that this illusion is based on drama because both White British and Asians continuously change their cultural and ethnic identities and introduce themselves again on British soil. The subversive influence of mimicry and the presentation of the power of performativity by the Asians reveal a dangerous threat to their lives in foreign countries. The protagonist Shahid Hassan always imitates the cultural values of the British but he remains too dissatisfied on British soil. 
Shahid has become the victim of ambivalence when he says,

Everywhere I went I was the only dark-skinned person. How did this make people see me? I began to be scared of going into certain places. I didn't know what they were thinking. I was convinced are full of sneering and disgust and hatred. And if they were pleasant, I imagined they were hypocrites. I became paranoid. I couldn't go out. I knew I was confused. But I did not know what to do. (Kureishi, 1995, p. 10).

Why does Shahid the victim of an ambivalent state of mind?

He is the victim of uncertainty because of the whites' rude and prejudiced attitudes towards him. They ridicule him for his black skin, spat on him, and called him a Paki, Paki, Paki, Out, Out, Out! Kureishi narrates heart-rending incidents from the perspectives of Shahid's childhood in his novel when Shahid's class-fellows wrote awkward sentences as "Paki Wog Fu*k of Home and called him as Paki, Paki, Paki, Out, Out, Out" (Kureishi, 1995, p. 73). This is the indication of his state of mind that how is he living in such a racial condition. Kureishi intends to unveil the biased West while portraying social, economic, racial, cultural, political, and religious identity crises in The Black Album. Under the impact of a racially charged atmosphere, the characters in The Black Album are unable to find out their true identity. Tahira, a female Muslim character exposes Western prejudice in a manner that it is very difficult to wear hijab. We were the dirty one in the eyes of westerners. Yesterday a man tried to rip off my scarf in the street saying that this is England, not Dubai (Kureishi, 1995, p. 105). Chad says in the history of everything, it is the strictest era of racism. "How can you not have picked up the vibe in this distorted way? There's a bit of Hitler in all white people - they have given that to you. It's all they have ever done for us (p.99)". Kaleta in her book Hanif Kureishi: Postcolonial Storyteller (1998) remarks about Kureishi's characters that they fight against ethnic prejudice, political hypocrisy, and economic failure in England. Their life is full of challenges of economic failures and national borders. In The Black Album, the Muslims protest against The Satanic Verses and raise slogans for their religious honor. Kureishi gives warning to the Muslims of the world on the dangers of British government policy towards them (Upstone, 2008, p. 06). Shahid portrays his picture as a dark-skinned person wherever he went under the psychological nervous condition. According to Shahid, dark skin causes inferiority complex as compared to white-skinned people. He feared racism in England and people's reaction in this regard (Kureishi, 1995, p. 10). He visits every place in London to escape from the racist attacks. He was aware of the bigotry of the whites against the non-whites from his childhood and realized that the whites were full of contempt, disdain, and loathing. And they were hypocrites if they seem pleasant. He became paranoid. He never compromises with his circumstances in respect to his attachment to a racist environment. So the novel depicts the racial tension in British. To eliminate the phenomenon of racism and stereotyping, Homi K. Bhabha plays a remarkable role in this aspect. He exposes the ethnic pigeonholing of the immigrants at the hands of the non-immigrants. According to him, it is necessary to revise the fixed social identity through the need for dialectical thinking. He critically explores the colonized identity and its exploitation at the hands of Westerns.

Shahid becomes the victim of an ambivalent state of mind when he says

"These days everyone was insisting on their identity,

Coming out as a man, woman, gay, black,

Jew - brandishing whichever features they could claim,

As if without a tag they wouldn't be human." (Kureishi, 1995, p. 155)

Why does Shahid become the victim of uncertainty and ambiguity? He is disappointed due to the anti-immigrant policies because the independence of British India resulted in causalities and animosity in religious, political, social, and economic matters (Archcroft et al., 2007, p, 276). A large number of Pakistani and Indian individuals sacrificed their lives for the sake of their freedom. Many of them migrated to other European countries especially France, Italy, Germany, and England. Young people like Shahid and Chili experienced the chanting of anti-Muslim slogans and the behavior of their Hindu neighbors outside their homes. At that time, Shahid watches this animosity in an intensified manner. This violent act does not stop him from being racist; he is vocal throughout the novel about his hatred of Pakistani people. This violent act is the indication of the racist attitudes of the White Englishmen towards the Pakistanis. In turn, the racism in England may not be decreased and the British government is not in a situation to eradicate this evil from its soil forever. According to Young (2005), due to the British's anti-immigrant policies, Kureishi's protagonist is dissatisfied with his representation in a biased environment. He always in search of his identity and he never adapted the Western society. Kureishi's protagonist tries his best to maintain his individuality under the antagonistic environment. That's why Shahid Hassan never compromises his individuality under the impact of severe racial circumstances. He remains torn between two cultures by possessing a love for English culture, English music, sex, drugs, and liberal ideology. The war between his care for Riaz, a religious leader, and his love for pop music remain continued till the end of the novel. His burning of the blasphemous book is the indication of his support for Riaz and his true well-wisher for the welfare of his race. After the death of his father, Shahid Hassan travels to London and gets admission here. He meets with Riaz Al Hussien, the leader of the Muslim fundamentalist group at Kent University, and Deedee Osgood his college lecturer. He prefers to stay in a hostel to avoid his family. He never compromises with the people whom he meets during his life and he always in quest of his independence and identity. His mind always oscillates between two cultures. 
Sometimes, he prefers Deedee Osgood over Riaz when Deedee calls Riaz Al Hussein an extremist. He tries to understand the status of Riaz and told it to Deedee that Riaz is working for the welfare of his immigrant community in London but she shows disagreement with this statement by saying that some people have passionate beliefs and anger. Do you have passionate beliefs and anger? and without that nothing could be done. He replied after hearing this that clever people like you are cynical and cunning. You never take any action by ripping everything to shreds. If you have everything your way, why would you want to change it? We are the victim of identity crisis and disintegration here (Kureishi, 1995, p.110). But on the contrary, Deedee tries her best to tempt Shahid to accept Western liberalism and Western culture.

Immigrants from all over the world come to London for the exploration of their dreams because London is a multicultural city having multi-shaded colors upon its geographical canvass. In that multicultural city of London, some societies faced racial attacks like the Muslim immigrants faced. The Black Album depicts the rude behavior and biased attitude of the white Londoners towards Muslims based on race, color, religion, and culture. In an environment of religious agitation, the novel has been set with Muslim injustices. Muslims were being harassed in the name of cultural, racial, and religious differences. Margaret Thatcher's policies were against the interest of Muslims. At that time the racial stereotyping of Muslims was very common in England.

According to John McLeod, Asians represent the invidious racial stereotypes in western countries (McLeod, 2000 p. 44). The protagonist Shahid Hassan tried his best to get out of this humid situation because he is entangled between liberalism and Islamic fundamentalism. Godlasky (2005 p. 83) observes Hanif Kureishi's characters are always in search of their identity and they are never sure who they are. Second-generation immigrants face a lack of identity because of the emergence of two definite cultures. Kaleta remarks that Hanif Kureishi experiments with new themes along with specific issues. Hanif Kureishi leaves an agitation among the new generation of immigrants by depicting racism, prejudice, stereotyping, and ethnicity along with their negative impacts upon immigrant Muslims. Kureishi shows restlessness in search of an identity of an individual by portraying Shahid's anxious soul. Shahid cannot accept western culture wholly and he is not in a position to reject it partially. Shahid's struggle for the realization of his identity is the indication of his leaving of home town and his preference to remains in the hostel. He is torn between western culture and Muslim identity from his childhood. The people around his surroundings used to abuse him Pakis, chinks, niggers, Irish, any foreign scum (The Black Album 1995 p.19). He got a chance to offer five times prayers with his cousins in Karachi instead of adopting western culture. His personality shatters under the impact of racial attacks. His western school class fellows teased him by calling him Paki when he was a child (The Black Album 1995 p.72). Due to the racial attacks in the school, he became a carelessness and negligent student of the school. He becomes seriously injured, bruises, wounds, and his bag was cut with blades or knives when he came back home from school. His mother does not show a strong reaction on this occasion because she remained under racial abusing and contempt.

\section{FINDINGS}

The researcher has found out the religious, economic, ethnic, cultural, and social factors behind the identity crisis faced by the protagonist. Hybridity, mimicry, assimilation, and ambivalence played a very vital role in the social life of Shahid Hassan. He is in between two cultures, the one in Indian culture and the other in English culture. He felt directionless due to the differences in cultures. He was treated with humiliation due to the biased and rude behavior of the whites.

\section{CONCLUSION}

From the above given discussion, it can be concluded that the protagonist in Hanif Kureishi's The Black Album faced an identity crisis in tormenting and perturbing the social order of England. Hanif Kureishi very well depicts the biased attitude and racial attacks of the whites on Muslim immigrants and tries to keep his readers busy to look at this global issue seriously. He also portrays the 1970s and the 1980s decades of London as full of religious and racial discrimination. Shahid and other characters of the novel highlight their crisis of identity on social, political, religious, and economic grounds. The first-generation immigrants like Riaz and Shahid represent social, and religious identity while being fixed with their Asian roots and traditions and they do not compromise with it, while on the contrary, the second-generation immigrants like Deedee and Zulma try their best to adopt the English culture and traditions to enjoy sex, drugs, rock and rolls, luxuries of English society. For adjusting themselves with the British culture, the characters try to imitate the cultural values of the Whites but this mimicry never fetched the desired effect for them and the result is simply ambivalent for them. The Whites consider themselves as superior and supreme race as compare to immigrants especially the Asian people and they do not take interest in accepting them. That is why, the Asian are deprived of their religious, personal, cultural, social and political identities. However, this idea is based on illusion because it indicates the false metaphysics of philosophical traditions of Western societies which have described discriminations as the refusal of hybrid and cultural identity and affixed this refusal to the minor group which is called Asian peoples. The novel shows that this illusion is based on drama because both White British and Asians continuously change their cultural and ethnic identities and introduce themselves again on British soil. The subversive influence of hybridity and the presentation of the power of performativity by the Asians reveal a dangerous threat to their lives in foreign countries. The protagonist Shahid Hassan always in quest of his identity and he remains in an ambivalent condition throughout the story. He is a hybrid character too because he is living between two cultures. The author, Hanif Krieshi himself is the victim of identity crisis in England and he saw the whole dilemma of identity crisis through his own eyes. Within the range of 
postcolonial criticism, this dilemma has led the novel to become hotly debated. So it is being discussed in the context of Salman Rushdie's The Satanic Verses.

\section{LIMITATIONS AND STUDY FORWARD}

After an in-depth analysis of the literature review, the researcher found that most of the studies deal with political identity. Likewise, the study contributes certain points which are realized after searching into the gaps in previous researches and adds some new ideas in different dimensions. According to my text knowledge, I could not find a work that covers economic, cultural, racial,

and social issues. An extensive review of the existing literature reveals that Kureishi's work has not been subjected to the aforementioned topic because most of the studies dealt with history as well as a political identity. My research here fills in the gap and incorporates most of the issues of an identity crisis.

\section{ACKNOWLEDGEMENT}

My deep appreciation is for those who did a lot in the completion of this paper. I am thankful to my supervisor Prof. Dr. M. K. Sangi whose nice way of supervision created a love for literature in my heart. He gave me perfect guidance and interest in this article. I also got aspiration from my co-supervisor Dr. Komal Ansari who always remains a loyal to me and guided me in how to write a manuscript with accuracy.

\section{CONTRIBUTIONS TO THE PAPER}

The present research paper is the contribution of the author and the co-authors of the Institute of English Language and Literature University of Sindh, Jamshoro. They have been contributed to the present research paper as under. The main author has contributed in being proposed the research topic, basic study design, and manuscript writing. The second author has contributed to Research Methodology, Data collection, and textual data analysis strategies, and the third author helps in writing the Literature review, employing the relevant theory and APA referencing style in true letter and spirit.

\section{REFERENCES}

1. Alexander, I. B. (2011). Freedom and the city: contemporary British fiction and the cultural politics of disenfranchisement. (Unpublished doctoral dissertation). University of York: UK. https://www.palgrave.com/ gp/book/9781137393715

2. Ashraf, M. (2005). Postcolonial Criticism: Famous Publisher.

3. Ashcroft, B., Griffiths, G., Tiffin, H. Ed., (2007). Post-Colonial Studies; the Key Concepts. Routledge Print.

4. Bhabha, H. K. (1994). Interrogating Identity: The Location of Culture. Routledge Print.

5. Ellingsen, L. H. (2012). An Englishman born and bred, almost Identity and Belonging in Hanif Kureishi 's The Buddha of Suburbia. (Master's Thesis, The University of Oslo, Norway). https://www.duo.uio.no/bits tream/handle/10852/34757/AnxEnglishmanxbornxandxbred-MA1.pdf? sequence $=1 \&$ isAllowed=y $($ June 10 , 2020).

6. Fanon, F. (1967). Black Skin, White Masks. Grove Press.

7. Felski, R. (2000). Nothing to Declare: Identity, Shame, and the Lower Middle Class. Publications of the Modern Language Association of America. https://doi.org/10.2307/463229

8. Grin, M. S. (2005). The Search for Identity in "The Buddha of Suburbia" by Hanif Kureishi. https://www.grin.com/document/388006. (June 28, 2020).

9. Greenham, D. (2018). Close Reading The Basics, Routledge Print.

10. Gilbert, B. M. (2001). Hanif Kureishi. Manchester: Manchester University Press Print.

11. Gergen, J. K. (1991). The Saturated Self: Dilemmas of Identity in Contemporary Life. Basic Books.

12. Godlasky, R.S. (2005). Envisioning the Post-Community in Contemporary British Fiction and Film. http://etd.lib.fsu.edu/theses_1/available/etd-11072005-201354/unrestricted/Godlasky_dissertation.pdf [Access ed 4 August 2012].

13. Gun, O. (1997). Through traveled eyes: representations of subcontinental migration. (Unpublished doctoral dissertation), UK. http://theses.gla.ac.uk/2923/1/1997orgunphd.pdf

14. Jameson, F. (1991). Postmodernism or the Cultural Logic of Late Capitalism. Duke University Press.

15. Kara, G. (2020). The Problem of Immigrant Identity In Buddha of Suburbia By Hanif Kureishi. Akademikdil Ve Edebiyat Dergisi, 4(1), 179-199. https://doi.org/10.34083/akaded.703403

16. Kaleta, C. K. (1998). Hanif Kureishi: Postcolonial storyteller. The University of Texas Press.

17. Kureishi, H. (1989). The Buddha of Suburbia. Faber and Faber Limited Press.

18. Kurieshi, H. (1995). The Black Album. Faber and Faber Limited Press.

19. Kureishi, H. (2005). Something to Tell You. Faber and Faber Limited Press.

20. Loomba, A. (1998). Colonialism/ Postcolonialism. Routledge Print.

21. Louis, W. R. (2013). Irrepressible adventures with Britannia: personalities, politics, and culture in Britain. I.B. Tauris.

22. McLeod, J. (2000). Beginning Postcolonialism. Manchester University press. 
23. Ranasinha. (2002). Hanif Kureishi: Writing the self. Manchester University Press. https://www.goodreads. com/book/show/50352615-hanif-kureishi

24. Rushdie, S. (1988). The Satanic Verses. Viking Penguin.

25. Rushdie, S. (1992). Imaginary Homelands: Essays and Criticism 1981-1991. Granta Books Print.

26. Schoene, B. (2009). The Cosmopolitan Novel. Edinburg University Press.

27. Said, E. (1997). Covering Islam: How the Media and the Experts Determine How We See the Rest of the World. First Vintage.

28. Said, E. (1979). Orientalism. First Vintage.

29. Thomas, S. (2005). A Monograph on Hanif Kureishi. Palgrave Macmillan:Basingstoke Press.

30. Upstone, S. (2008). A question of black or white: Returning to Hanif Kureishi's The Black Album, The Open Humanities Journal, 4(1), 1705-9100. https://www.postcolonial.org/index.php/pct/arti cle/view/679

31. Walsh, T. (2008). The in-betweeners: Irish animation as postcolonial discourse. Loughborough University.

32. Young, R. (2005). Colonial Desire, Hybridity in Theory, Culture and Race. Routledge Print. https://www.routledge.com/Colonial-Desire-Hybridity-in-Theory-Culture-and-Race/Young/p/book/97804150 $\underline{53747}$

33. Yousaf, N. (2002). Hanif Kureishi's The Buddha of Suburbia. Readers Guide. The Continuum International Publishing Group Inc. https://www.bloomsbury.com/us/hanif-kureishis-the-buddha-of-suburbia-97808264 $\underline{53242 /}$ 